\title{
New Frontiers of International Criminal Law: Towards a Concept of Universal Crimes
}

\author{
TERJE EINARSEN*
}

\section{Introduction to the notion of universal crimes}

Despite the ambiguities of international criminal law, serious crimes committed, organised, or tolerated by representatives of different kinds of national or transnational power structures are now of concern to the world community. These crimes may often occur in the context of armed conflict, as in the on-going civil war in Syria, ${ }^{1}$ but they may also form part of a pattern of aggressive behaviour by states or by powerful non-state actors within a society during times of relative peace. They are often directly linked to abuse of political or military systems or to an absence of effective state institutions able and willing to protect civilians against serious harm.

Under exceptional circumstances, similar grave crimes might also be committed by smaller groups without any linkage to a real power structure, or even by singular persons, cf. the notion of 'lone wolf' perpetrators of atrocities. The carefully planned terrorist bombing of government buildings in Oslo 22 July $2011,{ }^{2}$ and the politically motivated massacre and attempted group destruction of talented young members of the ruling Labour party at Utøya the same day, ${ }^{3}$ serves as a reminder that no society is immune from exposure to shocking crimes of global concern. The singular perpetrator of both these

Terje Einarsen is Professor of Law at the Faculty of Law, University of Bergen.

Syria is not a member of the International Criminal Court (ICC), but the UN Security Council may refer the situation to the ICC. A new Syrian government may also choose to accept the jurisdiction of the ICC. Alternatively, or in addition, a special international or national court may eventually be established for the purpose to prosecute those (most) responsible for grave crimes committed in Syria by all sides of the conflict, see e.g. 'The Chautauqua Blueprint for a Syrian Extraordinary Tribunal to Prosecute Atrocity Crimes' (Draft Statute of 3 October 2013).

2 This attack on Norwegian democracy and rule of law resulted in 8 dead and 9 seriously wounded, whereas more than 200 others were also wounded, as well as large material damages; see RG 2012 p. 1153.

At Utøya (a small island outside Oslo) 69 persons were killed and 33 others seriously wounded by gunshots. Many others were wounded, and many have suffered psychological damages, see RG 2012 p. 1153. 
atrocities was convicted for crimes of terrorism under Norwegian law. ${ }^{4}$ Whether these acts also constituted crimes under international criminal law, is a more intriguing question. This article discusses only normative and analytical preconditions to such concrete questions.

'International crimes', which may also be referred to as 'universal crimes' because of their inherent gravity and violation of universal values and interests, are attacks on the rule of law. They typically constitute transgressions of various social and moral norms, including human rights. Human rights are universal in the sense that every person has and should enjoy them. Similarly, no person should be exposed to universal crimes. However, these aspirations do not always correspond to legally binding rights and obligations or to mechanisms of enforcement under current international law. We are still living in an age of uncertainty regarding which specific types of crimes are punishable directly under international law and which might therefore be prosecuted on a regular basis before international courts.

Drawing on a recently published book by the author, which elaborates on general issues involved in classifying certain offences, this article outlines a concept of universal crimes. ${ }^{5}$ It argues that 'universal crimes' is a useful supplement and alternative to the traditional term 'international crimes', when analysing this field of law and discussing its limitations and possibilities for the future. The universal crimes concept is meant to constitute a broader term. It includes current international crimes, equivalent with universal crimes lex lata, i.e. crimes and conduct for which criminal liability already exists directly under international law. But it also embraces the notion of universal crimes lex ferenda, i.e. criminal liability that ought to exist based on principled criteria ('international crimes lex ferenda' would probably be considered a contradiction in terms). More importantly, the concept of universal crimes urges a deeper analysis as to why some offences and modes of conduct are and ought to be considered crimes with direct liability under international criminal law, and others not. ${ }^{6}$

$4 \quad$ Anders Behring Breivik was sentenced to special punishment for a period of between 10 and 21 years in prison ("forvaring"), with a view to further prolongation of the sentence, possibly for life.

5 See Terje Einarsen, The Concept of Universal Crimes in International Law, (Torkel Opsahl Academic Epublisher (TOAEP), Oslo, 2012). Hardcover available e.g. at www.amazon.co.uk while free online access is available at www.fichl.org/publication-series/. [Last accessed 1 October 2013]. The book is the first in a four-part series entitled Rethinking the Essentials of International Criminal Law and Transitional Justice. The 'Universal Crimes Project' is an independent research program founded by the author. Its main purpose is to contribute to the development of laws and mechanisms relevant to combatting grave crimes, in compliance with human rights norms and the underlying public interests of international criminal law and criminal justice. See also www.uib.no/persons/Terje.Einarsen\#prosjekt.

6 The concept of universal crimes concerns other legal and transitional justice issues as well, such as the scope for liability for different kinds of participation in universal crimes, and the legal consequences of universal crimes. See also Einarsen (2012) 'Preface', pp. iii-iv. 
The object of this article is to propose 'universal crimes' as a new and comprehensive concept, with the potential to provide a unified perspective on this part of international law, in particular in response to the problem of fragmentation. ${ }^{7}$ The fragmented nature of international criminal law comprises several sub-regimes, including international or internationalised criminal courts that apply similar, but to some extent also different, substantive rules and may use different methodological approaches. The material jurisdictions of these courts have often been more limited than that which international law arguably allows. Consequently, while the legal status of certain crime types (e.g. crimes characterised as genocide, crimes against humanity, and war crimes) and individual liability for certain modes of participation in system criminality have been clarified (joint perpetration, incitement, accessoryship, etc.), the legal status of other crime types and acts of participation still remain controversial or in limbo. Apart from political causes and institutional explanations, the question is whether this situation is also due to a lack of a more systematic, principled reasoning in international criminal law scholarship.

When systematically considered, the concept of universal crimes may serve to meet some of the pressing need for synthesising seemingly isolated bits and pieces of international criminal law. This concerns the lawful application of certain identifiable crime types and modes of participation under general international law, including direct criminal liability before international courts in the future and accountability for such crimes more broadly. This project to advance the concept of universal crimes should therefore be seen in light of the reasoning of the International Law Commission, which has claimed that international law is a legal system and that its rules and principles "should be interpreted against the background of other rules and principles".

This article focuses on universal crime types and categories, and not so much on schemes of liability for various participants in universal crimes. ${ }^{9}$ It is divided into six more parts. The following section proceeds with a brief introduction to crimes with uncertain status under international law and the suggestion of a principled way forward based on five cumulative and interrelated criteria. Emphasis here is put on 'gravity' as key to universal crimes (section 3). The fourth section seeks to establish useful definitions of universal crimes. This section also clarifies the relationship between universal crimes lex lata and universal crimes lex ferenda, and non-universal crimes. The essential and com-

Gradual expansion and diversification is a general problem in international law, and the International Law Commission has therefore put 'fragmentation' on its formal agenda. See International Law Commission (ILC), "Fragmentation of International Law: Difficulties Arising from the Diversification and Expansion of International Law" in Analytical Guide to the Work of the International Law Commission 1949-1997, 1998.

$8 \quad$ ILC, "Conclusions of the Work of the Study Group on the Fragmentation of International Law: Difficulties Arising from the Diversification and Expansion of International Law", 2006, conclusion no. 1, reprinted in Yearbook of the International Law Commission, 2006, vol. II, part II.

9 A forthcoming book, co-authored with Dr Joseph Rikhof, Senior Counsel at the Crimes against Humanity and War Crimes Section of the Canadian the Department of Justice, will analyse issues of punishable participation in universal crimes. 
mon building blocks of all universal crimes, the underlying crimes at a particular crimes scene, and the contextual 'gravity clauses' that make the crimes universal, are explained in section 5. This brings us to the last point: the need to develop a 'United Nations Declaration on Universal Crimes' (section 6), before finally, a few concluding remarks.

\section{Crimes with uncertain status: a way forward}

The Nuremberg and Tokyo trials laid the foundation for contemporary international criminal law (ICL). Today, ICL is an established part of international law, although it is still, according to Cassese, "a relatively new branch of international law" and "still a very rudimentary branch of law". ${ }^{10}$ ICL can be said to encompass "all norms that establish, exclude or otherwise regulate responsibility for crimes under international law". ${ }^{11}$

More than six decades later, there is still much uncertainty about which types of grave breaches of fundamental norms are defined as punishable crimes under international law. As has been stated by Bassiouni, the writings of scholars have in fact been 'uncertain', if not 'confused. ${ }^{12}$ This means that there is no agreed set of criteria for the identification of international crimes, and no enumerative definition of sound authority. ${ }^{13}$

However, the most disputed areas today are not the ones that were contested initially, when the United Nations paradigm of international law was established. ${ }^{14}$ Hence the preferred solution by many experts and authors to the problem of identifying those crime types for which there exist international criminal liability, has been to stipulate a shortlist of international crimes, typically war crimes; crimes against humanity; genocide; and

Antonio Cassese, International Criminal Law, (Oxford University Press, Oxford, UK, 2003), pp. 16-17. The same characterisations are upheld in Antonio Cassese, International Criminal Law, 2nd ed., (Oxford University Press, Oxford, UK, 2008) p. 4.

11 Gerhard Werle, Principles of International Criminal Law, (TMC Asser Press, The Hague, 2005), p. 25; upheld in Gerhard Werle, Principles of International Criminal Law, 2nd ed., (TMC Asser Press, The Hague, 2009) p. 29.

12 M. Cherif Bassiouni, “International Crimes: The Ratione Materiae of International Criminal Law", in International Criminal Law, vol. 1, Sources, Subjects, and Contents, 3rd ed., (ed. M. Cherif Bassiouni), Martinus Nijhoff/Brill, Leiden, Netherlands, 2008 pp. 132-133, states, "The writings of scholars are uncertain, if not tenuous, as to what they deem to be the criteria justifying the establishment of crimes under international law. Moreover, there is a great deal of confusion in the writings of scholars as to what constitutes an international crime, and how these crimes should be referred to".

13 The methodological approaches to these issues have also been quite different in the literature, spanning mere descriptions of crimes in international court statutes to attempts of analytical classifications; empirical surveys of vast amounts of treaty law concerned with the suppression of various crimes; and careful assessment of customary international law. An interesting analytical model is set forth by Robert J. Currie, International \& Transnational Criminal Law, (Irwin Law, Toronto, 2010) pp. 17-21 (distinguishing between 'international core crimes', 'other international crimes', 'transnational crimes of international concern', and 'transnational crimes of domestic concerns'). 
the crime of aggression. ${ }^{15}$ These are often referred to as the 'core crimes' of international criminal law, although many scholars have also left out or paid less attention to the crime of aggression.

Examples of crime types with uncertain status under general international law lex lata include crimes of terrorism, crimes against the United Nations and internationally protected persons, crimes of group destruction not encompassed by the Genocide Convention (e.g. intended destruction of a political group), piracy crimes, and excessive use and abuse of authorised power. The last category of so-called discrete crimes includes, but is not limited to, possible crimes under international law such as isolated acts of torture, enforced disappearance of persons, and unlawful targeted killing of civilians, when linked to powerful parts of society. Even though they are not systematic or widespread (if they were, they would constitute crimes against humanity), these singular acts are always serious. They are contrary to fundamental universal values and, furthermore, potentially dangerous to the rule of law when committed, organised, or tolerated by a high-level public official or other person acting as authorised within a power structure. It is unfortunate that current ICL appears to be still undetermined on many such critical issues. While opinions among scholars and other stakeholders differ with regard to what constitutes punishable conduct under general international law, the specific lists of crimes embodied in statutes of international tribunals - for the purpose of determining and confining their respective material jurisdiction - are also influenced by various pragmatic considerations, and do therefore not necessarily represent the limits of ICL lex lata.

There is however no common international legislature that can easily settle the issue by deciding which crimes are currently crimes under general international law. The thesis of this article is that some of this uncertainty - which is explainable and sometimes policy-driven - might be gradually reduced through careful analysis of the relevant 'crime criteria'. From the perspective of the rule of law as well as scholarship, these criteria must, in principle, be identifiable, to enable consistent application. Finding such common criteria and reaching consensus on specific crime categories, however, has been difficult, despite suggestions made by legal analysts and considered by the International Law Commission.

This suggests that the underlying theories of ICL may not be sufficiently developed. It is also possible that large gaps remain between common normative values of the world community and other interests affecting decisions on international law. Despite the lack of clear common theories and the presence of conflicting state interests, however, progress has been made in adapting international law to conform more adequately to proclaimed goals of the UN Charter and similar ideals. Since World War II, and particularly in recent decades, there have been some impressive results in using international law to combat grave crimes. This is noteworthy since such crimes are most commonly commit- 
ted, initiated, or tolerated by powerful persons, including heads of state. Enforcement on this basis now seems to be spreading around the globe; one study showed that between January 1990 and May 2008, 67 heads of state or government from 43 countries had been formally charged with or indicted for serious criminal offences ( 32 defendants from Latin America, 16 from Africa, 10 from Europe, seven from Asia, and two from the Middle East). ${ }^{16}$ The cases were almost evenly divided between human rights and corruption cases. Among the former, several cases seem to have concerned possible 'universal crimes' cases. The number has since surely increased. This gives us some confidence that improved analysis of ICL eventually may provide international actors with even better tools for ensuring systemic consistency and expanding the scope for legitimate changes in policy.

Inductively obtained on the basis of a detailed descriptive survey of various relevant legal sources, and a classification typology undertaken by the author, it is held that certain necessary and sufficient criteria must be in place before any type of proscribed conduct can be considered a crime under general international law. ${ }^{17}$ Ultimately, all international crimes and universal crimes lex lata must meet the following five cumulative and interrelated conditions:

- The type of conduct manifestly violates a fundamental universal value or interest.

- The type of conduct is universally regarded as punishable due to its inherent gravity.

- The type of conduct is recognised as a matter of serious international concern.

- The proscriptive norm is anchored in the law-creating sources of international law.

- Criminal liability and prosecution do not require consent of any concerned state.

For reasons of space, the next section concentrates only on the second requirement, which is key to understanding the concept of universal crimes.

\section{Gravity as key to universal crimes}

Arguably, the most important key to understanding universal crimes is 'gravity'. The relevant type of conduct must be universally regarded as punishable due to its inherent gravity, allowing for punitive sanctions (retributive justice) as a legitimate response, regardless of the status of the victims, and the time and place of the actual crime scene. This means that such acts should be widely condemned or considered clearly undesirable by the inLutz and Caitlin Reiger, Cambridge University Press, Cambridge, UK, 2009, p. 285 and p. 291.

17 For more details on the five criteria and their empirical and analytical basis, see Einarsen (2012), especially pp. 231-247. 
ternational community, and that the criminal nature of such acts should be recognised, regardless of how the acts are otherwise characterised in social, political, or legal terms.

The core meaning of 'gravity' in international criminal law can be usefully considered a function of two main parameters: the seriousness in qualitative and quantitative terms of the crime level at each particular place ('universal crime scene'), defined by the underlying crimes committed within a certain socio-political context ('universal crime scenario'), and the level of responsibility for the crimes usually within the power structures which can be considered in empirical terms to be collectively responsible for the crimes. A universal crime scene can be an exact location, for example a detention centre, a small village, a school or church, even a house, but it might also be taken as a wider geographic area, such as a town or even a city or whole country. The relevant socio-political context is considered in legal terms to be part of the definition of the crime category in question, for instance, a state of armed conflict with respect to war crimes or a "widespread or systematic attack directed against any civilian population" with respect to crimes against humanity. ${ }^{18}$

Determining the level of responsibility requires a principal focus on the rank and role of the primary leader allegedly responsible and of other high-ranking personnel, and their concrete modes of participation. However, the most notorious offenders positioned at intermediate or low levels of the power structure may also, by the scale and cruelty of their involvement, be assigned a high level of responsibility. In other words, the 'responsibility level' is not necessarily determined only by a person's formal or de facto position within the relevant power structures, but in special cases wholly or primarily by the suspect's own acts at the concrete crime scenes.

In a seminal article that applied the notion of 'indirect perpetration' to leaders, Roxin noted already in 1963 the strong causal relationship between organised power structures and 'collective crimes.' ${ }^{19}$ In his opinion, one may understand the acts of leaders from the point of view of criminal law in two ways: as collective crimes or as individual acts, but "[n]either of the two viewpoints can, in isolation, entirely encompass the substantive criminality of the occurrences". ${ }^{20}$ Roxin highlighted in particular the feature of control over an organised power structure by actors who remain behind the scenes, suggesting that an absence of proximity to the crime in question might be "compensated by an in-

18 See ICC, Report of the Preparatory Commission for the International Criminal Court, Addendum Part II, "Finalised draft text of the Elements of Crimes", PCNICC/2000/1/Add.2, 2, November 2000, Article 7(1) (a), Crime against humanity, of murder.

19 Originally published in German, the article has recently been republished in translation. Claus Roxin, "Crimes as Part of Organised Power Structures", in Journal of International Criminal Justice, 2011, No. 9, pp. 193-205. See also Gerhard Werle and Boris Burghardt, "Claus Roxin on Crimes as Part of Organised Power Structures: Introductory Note”, in Journal of International Criminal Justice, 2011, No. 9, pp. 191-193.

$20 \quad$ Roxin (2011), supra note 19, p. 194. 
creasing degree of organisational control by the leadership positions in the apparatus". ${ }^{21}$ In other words, the further removed a punishable participant is, in structural terms, from the victim and the direct criminal act, the more responsibility he bears for the universal crimes committed. ${ }^{22}$ Roxin underlined that the number of victims is not conclusive in determining perpetration at the highest level; "[if] only a single person had been persecuted, the person behind the scenes would still have to be convicted as a perpetrator". ${ }^{23}$

The assumption underlying this principle is very important with respect to the concept of universal crimes itself, and thus for our purpose here. But it also indicates that the parameters of gravity assessment may affect related issues such as the classification, content, and applicability of the different modes of punishable participation under international criminal law. For instance, if a certain mode of high-level participation tends to result in large-scale universal crimes, this weighs in favour of criminalisation and might affect the interpretation of written provisions. It should also be noted that while gravity is a defining aspect of universal crimes, and affects extended liability, gravity assessment is relevant also to international law enforcement, (suspected gravity may motivate the establishment of ad hoc tribunals), prosecutorial decision-making, ${ }^{24}$ and sentencing. ${ }^{25}$

\section{$4 \quad$ Seeking useful definitions of universal crimes}

\subsection{Some points of departure}

May it be useful to gradually replace the concept of international crimes with the concept of universal crimes in further academic analysis and legal debates? This is surely a difficult case to argue, since 'international crimes' has become the predominant term of art.

Changing terminology in a field such as international criminal law is furthermore a process that involves considerable debate and reflection by a variety of stakeholders,

$21 \quad$ Ibid., p. 200.

22 Ibid. "We can see that the objective elements of organisational control are very clearly delineated here: whereas normally, the farther removed a participant is from the victim and the direct criminal act, the more he is pushed to the margins of events and excluded from control of the acts, in this case the reverse is true".

$23 \quad$ Ibid., p. 201.

24 A number of different issues related to prosecutorial discretion at international tribunals may arise, making this a recurring theme in the ICL literature and to some extent for international jurisprudence generally. See, e.g., Morten Bergsmo (ed.), Criteria for Prioritizing and Selecting Core International Crimes Cases, 2nd ed., (FICHL Publication Series No. 4, Torkel Opsahl Academic EPublisher, Oslo, 2010). For an instructive article on lessons learned and best practices from international tribunals, see Xabier Agirre Aranburu, "Gravity of Crimes and Responsibility of the Suspect", in Bergsmo, 2010, pp. 205-234.

25 See Mark A. Drumbl, Atrocity, Punishment and International Law, (Cambridge University Press, Cambridge, UK, 2007), p. 64. Drumbl concludes that according to the jurisprudence of the ICTY and ICTR, "the gravity and egregiousness of the crimes [can be] identified as the primary consideration in imposing sentence". 
which means that it inevitably takes time. However, time is ripe for analytically rethinking the essentials of international criminal law for the following reasons: First, the body of ICL has matured in recent decades. Second, ICL is now being implemented and enforced in many national jurisdictions. Third, practitioners are faced with substantial legal uncertainty that needs to be resolved, in a field of law that deals with fundamental issues of justice.

There may be particular advantages in employing the concept of universal crimes rather than international crimes. The first advantage is that the adjective 'universal' in 'universal crimes' highlights the justification for ICL in common fundamental values and interests that are embedded in the UN paradigm of international law, while the adjective 'international' in 'international crimes' implies a bias towards the sovereignty of states and the relationships between states. This bias is clearly problematic within this particular field of international law, which consists of so many jus cogens norms that states are obliged to respect and implement for basic reasons of criminal justice. Furthermore, a concept of universal crimes based on sound general criteria provides a sufficiently flexible and indeed more consistent framework for critical appraisal of possible incorporations of new crimes and extended liability under international law.

Just as human rights are universal, so should substantive legal norms only be recognised as falling within the scope of international criminal law when they fulfil the full test of universality. Only then can the relevant crimes meet the common threshold in compliance with the general principles of the UN paradigm of international law. It follows that all crimes meeting these criteria should be recognised as universal crimes. It is important to underline that the defining criteria as briefly set forth above are closely linked to actual developments in international legal and political practice, and that the crucial distinction between lex lata and lex ferenda is sustained within this universal crimes framework.

\subsection{Different kinds of definitions}

A definition may be 'descriptive' of the general use of a particular term within a population as a whole or within a specific group of people, such as judges at international courts and/or legal experts or legal writers. A definition may also be 'stipulative' of the meaning intended by a particular speaker or writer, often in the context of a particular work or act of communication. In practice, it is not always clear whether a particular definition is descriptive or stipulative, or both. A 'normative' definition, on the other hand, seeks to design a recommended meaning of a term, that is, how it should be used. For some purposes, it might be useful to combine different kinds of definitions for the purpose of clarifying a certain subject matter.

With respect to universal crimes, one may usefully further distinguish between 'conceptual' and 'enumerative' definitions, and between 'legal' and 'theoretical' definitions. Thus a conceptual definition is based on general criteria, such as the five conditions pro- 
vided at the end in section 2 above. An enumerative definition of universal crimes would be based on the listing of concrete criminal acts (using less general concepts). The rather complex and detailed enumerative crime definition set out in the book on universal crimes thus included three abstract 'classes' of universal crimes ('universal core crimes'; 'other universal crimes against the peace and security of mankind'; and 'universal crimes not dependent on the existence of threats to international peace and security'), 10 universal 'crime categories' (e.g. 'genocide') and 150 specific crime types (e.g. 'killing with intent to destroy, in whole or in part, a national, ethnical, racial or religious group, as such'). Of the 150 crime types, 135 were considered crimes lex lata and 15 considered crimes lex ferenda. ${ }^{26}$

Legal definitions are normative definitions of a special kind, insofar as they usually concern how legal terms should be interpreted or applied as parts of legal norms. By 'legal norm' is here meant - as a stipulated definition - 'a rule either proscribing or prescribing a kind of conduct, for all people or for a group of people in a special situation, or for officials in a particular role, which in some way is upheld by sanctions or possible sanctions within a system of law'. Complete legal norms typically consist of certain legal conditions along with certain legal consequences that should follow when all the necessary and sufficient conditions are fulfilled ('if $a, b$, and c, then $x$ and $y^{\prime}$ ). When legal terms are authoritatively defined, for example, in a statute or a treaty, the intention is to determine the content of the law (how it should be interpreted and applied). Whereas some legal definitions are conceptual in structure, others are enumerative. Strict legal definitions are meant to express the law as it is (lex lata), as opposed to the law as it ought to be (lex ferenda).

A theoretical definition of universal crimes, on the other hand, should clearly define the concept in such a way that it includes all acts correctly identified as universal crimes while excluding all acts that are not universal crimes. In addition, a theoretical definition should help build a theory that informs a particular conception of universal crimes. It should lay out a certain way of thinking about crimes under international law and the essentials of international criminal law and transitional justice. ${ }^{27}$ Such a general definition

26 For the complete list with some explanation, see Einarsen (2012) pp. 319-328. See www.fichl.org/publication-series/ No. 14 (pp. 319-328). As noted there, the list should still be considered preliminary and incomplete.

27 Whereas international criminal law (ICL) is primarily about the international rules, institutions, and judgments concerned with crimes under existing ICL, and mainly studied by lawyers, 'transitional justice' as an academic field is focused more on victim groups, political processes, regime changes, and other aspects of different justice mechanisms. The two fields are, however, concerned with much the same crimes and are in several ways closely related. The concept of transitional justice consists of "both judicial and non-judicial processes and mechanisms, such as truth-seeking, prosecution initiatives, reparations programmes, institutional reform, or an appropriate combination thereof". UN General Assembly, Annual Report of the United Nations High Commissioner for Human Rights: Analytical Study on Human Rights and Transitional Justice, A/HCR/12/18, 6 August 2009, p. 4, para. 3. Transitional justice can also be seen as a practical response to systematic or widespread violations of human rights, seeking recognition for victims and promoting 
would have to be conceptual, or conceptual in combination with enumerated elements. It would not necessarily be a strict legal definition, but may include elements of lex ferenda and descriptive content as well.

\subsection{Legal and theoretical definitions of universal crimes}

In seeking a theoretical definition of universal crimes, both legal science and other fields of scholarship may be relevant. This is a challenge that also pertains to many other concepts of importance to the rule of law, 'human rights' being a particularly apt example. When the UN Charter and the Universal Declaration of Human Rights were adopted after World War II, the legal status and consequences of the rights proclaimed were still unclear under international law. In hindsight, one can see that the normative core of human rights immediately became part of the general principles of international law lex lata, whereas other human rights norms, and their softer edges, remained for a while in the sphere of lex ferenda. Over time, additional human rights have clearly become part of binding international law, as indicated by the term 'international human rights law'. In other words, the concept of human rights preceded its full legal content, and the legal development of human rights law continues. A similar process may apply to the concept of universal crimes, covering both potential crimes lex ferenda and established crimes lex lata under international law.

This implies that a theoretical definition of universal crimes should be wide enough to cover universal crimes lex ferenda, precise enough to exclude acts that are not universal crimes, useful for the legal and other professions, and conceptually relevant for interdisciplinary fields dealing with the same subject matter, such as transitional justice. A theoretical definition of universal crimes should build on a legal definition. Based on the set of necessary and sufficient criteria for recognising crimes under international law, a conceptual legal definition of universal crimes would be:

\footnotetext{
The term 'universal crimes' applies to conduct which (1) manifestly violates a fundamental universal value or interest, provided that the offence is (2) universally regarded as punishable due to its inherent gravity, (3) recognised as a matter of serious concern to the international community as a whole, and (4) proscribed by binding rules of international law, and provided that (5) criminal liability and prosecution is not dependent upon the consent of a concerned state (the territorial state where the crime was committed or the national state of an alleged perpetrator or victim).
}

This definition of universal crimes is precise enough to exclude acts that are not universal crimes lex lata, and thus potentially operational for the legal profession. The results it

possibilities for peace, reconciliation, and democracy through a holistic approach, see International Center for Transitional Justice, "What Is Transitional Justice?" 2009, available at http://www.ictj.org/publication/ what-transitional-justice, [last accessed 1 October 2013]. 
may produce when employed in legal analysis may also be useful for other professions and political actors in international law. But it is too narrow and too abstract to provide a theoretical definition with general application.

Nevertheless, our legal definition may serve as a basis for developing a theoretical definition. First, by combining criteria (1) and (2), we can usefully define universal crimes lex ferenda ${ }^{28}$ and simultaneously distinguish these crimes from 'non-universal crimes'. Secondly, by further adding two empirical elements to provide accessible and sufficient descriptive content we arrive at the following:

The term 'universal crimes' shall apply to any conduct that manifestly violates a fundamental universal value or interest, is universally regarded as punishable due to its gravity, and is usually committed, organised, or tolerated by powerful actors, and which therefore may require prosecution before international courts.

This theoretical definition may thus serve as a tool particularly for identifying possible universal crimes lex ferenda. Within this system of thought, all universal crimes lex lata are also universal crimes lex ferenda, just like internationally binding human rights are and should be a reflection of genuine 'human rights' preceding binding laws. Conversely, the last three criteria of the legal definition (3-5) not included in the theoretical definition may inform the theoretical definition; with the aid of these three criteria, one may discover the international legal and political implications emerging from the core parts of the theoretical definition. Hence, the two definitions serve different purposes, but reinforce each other.

\subsection{Universal crimes and non-universal crimes}

The relationships between universal crimes lex lata (the law as it is) and lex ferenda (the law as it ought to be), and non-universal crimes (crimes of a different nature than universal crimes), can be illustrated in different ways, for example by the figure below:

28 Universal crimes lex ferenda are offences with the potential of becoming universal crimes lex lata. 'Non-universal crimes' do not have that potential, at least not within a foreseeable future. 
Figure 1: Universal crimes lex lata and lex feren$d a$, and non-universal crimes. Source: Author

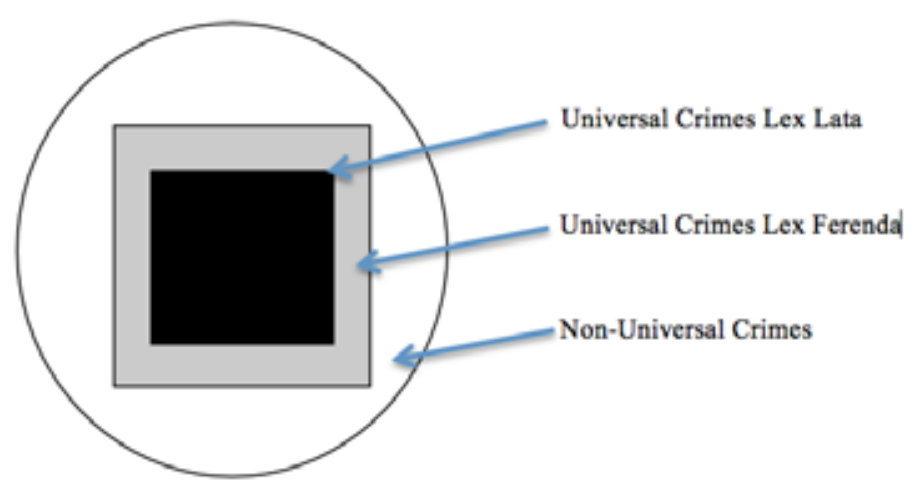

The outer white area represents non-universal crimes. The black inner square represents universal crimes lex lata. These crimes meet all five criteria of the legal definition of universal crimes. The grey square represents universal crimes lex ferenda, the most interesting category from a theoretical perspective. These kinds of potential crimes always meet the first two of the five criteria of the legal definition set forth above: they concern conduct that manifestly violates a fundamental universal value or interest and are universally regarded as punishable due to its inherent gravity. In addition, these crimes lex ferenda may fulfil one or two of the other criteria as well. Their possible future legal status as crimes lex lata depends upon the development of international law. It is noteworthy that with regard to some universal crime types lex lata, uncertainty exists with respect to their legal status, so in reality the boundaries are not as clear as in the figure. The same can be said for the boundaries between universal crimes lex ferenda and non-universal crimes. Different analysts and actors will make different assessments also in the future. This would be so whether or not the analysis and suggestions here are taken into consideration.

The proposed theoretical definition of universal crimes covers in principle the same ground as the legal definition extended to crimes lex ferenda. It explains concisely why a certain conduct ought to be considered a universal crime: because it clearly violates fundamental universal values or interests; is universally regarded as punishable due to its gravity; is usually committed, organised, or tolerated by powerful actors; and therefore may require prosecution before international courts. While the latter prosecutorial element is not a necessity as long as the crimes are fairly and effectively prosecuted in the concerned national jurisdictions, these crimes cannot, by their very nature, be left entirely to the discretion of individual states. Quite often, the incumbent administration, the military, or other public officials are implicated in universal crimes, or sufficiently 
competent and independent prosecutors and courts are not available. Sometimes both obstacles apply simultaneously.

In conclusion, the theoretical definition demonstrates a way of thinking about crimes under international law, which implies a particular conception of universal crimes. It forms part of a theory on the essentials of international criminal law and transitional justice within the existing UN paradigm of international law.

\section{$5 \quad$ The essential building blocks of universal crimes}

Universal crimes may also be divided into four different analytical classes, reflecting different levels of abstraction:

1. Universal crime categories

2. Universal crime types

3. Concrete universal crimes

4. Individual universal crimes

'Concrete universal crimes' (3) and 'individual universal crimes' (4) are of interest with respect to certain specific issues that lie at the crossroads between law and facts in decision-making processes. The distinction between 'crime categories' (1) and 'crime types' (2), however, is crucial to a proper understanding of what universal crimes are. We may here recall that the notion of 'core crimes' contains genocide, crimes against humanity, crimes of aggression, and war crimes. They are all considered crime categories in our scheme, and in turn, each category contains several specific universal crime types.

Importantly, a universal crime type is essentially a complete universal crime, setting forth all the necessary and sufficient material crime elements of a distinct universal crime. The relevant crime elements may include particular mental or subjective elements of certain crime types (apart from ordinary intent as contained more generally in criminal liability law). This is the case when such elements by necessity characterise the particular crime, as, for instance, with crimes of genocide and terrorism, and with certain types of war crimes. Whether or not such elements are included, however, each universal crime requires two main components or 'building blocks': the existence of an underlying crime and a contextual gravity clause.

Consequently, a crime type is not equivalent to an underlying crime as such, for example, an act of unlawful killing or torture. Rather, a specific universal crime type requires a combination of two components: (a) the underlying crime (for example, killing), and (b) the nexus to a particular gravity clause inherent in each particular crime category. All universal crimes in fact follow the same scheme, be it crimes of genocide, crimes against humanity or others.

It might be useful at this stage to explain how the gravity clauses generally relate to the other building blocks of universal crimes, especially the component of underlying 
crimes. Figure 2 below illustrates this with reference to the early stages of investigation and prosecution, but it should be noted that the relationship between a gravity clause and an underlying crime is the same when the judges are applying the substantive rules of ICL at the next stages of the criminal law procedures.

Figure 2: Investigating and prosecuting universal crimes. Source: Author

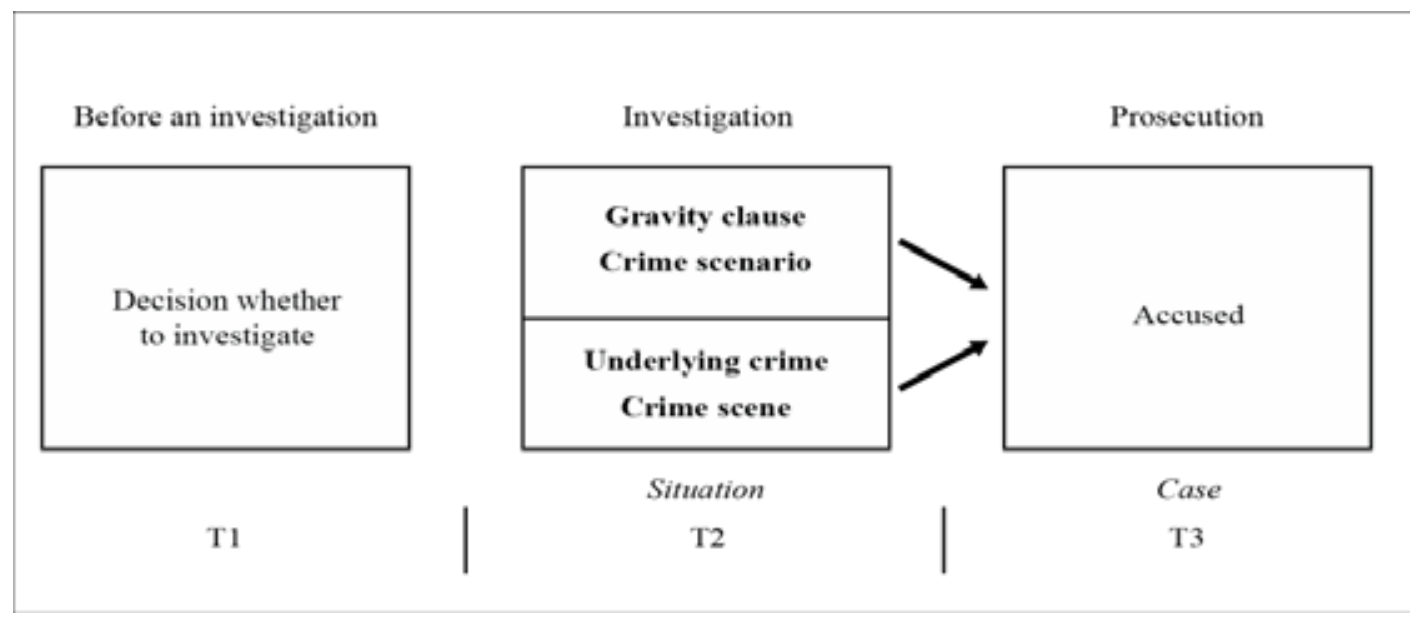

In principle the model is the same, regardless of the prosecutor, court, or universal crime types. At the outset (T1) one needs to determine whether there is sufficient reason to believe that universal crimes have been committed in a particular situation and that an investigation is warranted. If an international court with adequate jurisdiction has not already been established, independent experts or a fact-finding mission appointed by the Security Council or other UN bodies might carry out the preliminary examination. At the national level, if the prosecutors or courts do not have the required jurisdiction of competence to examine universal crime cases on their own initiative, a government may appoint a truth commission or similar body to examine the facts. Whether a formal investigation will ever be opened in such cases will also depend on various political and other factors.

If a preliminary examination leads to the conclusion that an investigation should be opened, for the purpose of potentially identifying individual suspects for prosecution, a factual and legal framework for the investigations and prosecutions should be utilised or considered for the relevant geographic areas and crime types. This might necessitate the establishment of a new ad hoc international criminal court with adequate jurisdiction and resources, if the International Criminal Court (ICC) does not have jurisdiction under the Rome Statute and the Security Council does not refer the situation to the ICC.

In the subsequent investigation of universal crimes (T2), a number of different prosecutorial considerations may apply with regard to selection and prioritisation, as mentioned earlier. Eventually, however, investigators must identify the underlying crimes and 
their nexus to a specific gravity clause with respect to individual suspects. In practice, this means that the concrete universal crimes must be identified by reference to a relevant 'universal crime scene', determined in relation to location, time, specific underlying crimes (for example, killing), and, as far as possible, individual victims and perpetrators. In addition, the underlying crimes must be linked to a legally relevant factual context, what might be termed a 'universal crime scenario'. A relevant crime scenario is determined by the possible facts corresponding to the normative elements of a gravity clause, for example, 'a widespread or systematic attack directed against a civilian population' in a particular situation, or the existence of 'intent to destroy' a concrete group. Only when the underlying crimes committed (or planned) at the crime scene are sufficiently linked to a relevant universal crime scenario will it be legally possible to prosecute a person accused of universal crimes (T3).

This theory of the inherent gravity clauses has important repercussions for the classification and definition of several crimes that might be classified as universal (or international) crimes, but that currently have a disputed legal status under international law even though some of these crimes have received much scholarly and policy attention, for example, terrorism, piracy, isolated acts of torture, and targeted killing. ${ }^{29}$

\section{Developing a United Nations Declaration on Universal Crimes}

The legality principle in international criminal law has several features. ${ }^{30}$ Of special interest here are the requirements of 'double legality' before international prosecution can take place. First, the relevant crimes must fall within the jurisdiction of an international tribunal established for the purpose of such prosecution, as explicitly stated in its statutes. Secondly, the crimes included in the statutes must also be crimes according to general international law. Prosecution of other crimes types at an international tribunal, e.g. of crimes according to the national criminal laws of the territorial states where the crimes were committed, will require special provisions in the statutes and the consent of the concerned state(s) to apply domestic law before the tribunal.

Perhaps surprisingly then, the international legality principle, also as stated in international human rights law, remains unclear with respect to which crimes actually consti-

29 Except for the latter, the other categories are discussed within a 'universal crimes' framework at different places in Einarsen (2012) especially the status of terrorism (pp. 266-274) and piracy crimes (pp. 306-313) under current international law. On targeted killing within a United Nations paradigm more generally, see e.g., UN General Assembly, Human Rights Council, Report of the Special Rapporteur on Extrajudicial, Summary or Arbitrary Executions, Philip Alston, Addendum: Study on Targeted Killings, A/HRC/14/24/Add.6, 20 May 2010. See also Nils Melzer, Targeted Killing in International Law, (Oxford University Press, Oxford, UK, 2008).

30 On this principle, see e.g. Kenneth Gallant, The Principle of Legality in International and Comparative Criminal Law, (Cambridge University Press, Cambridge, UK, 2009). 
tute criminal offences under general international law, for example under Article 15(1) of the International Covenant on Civil and Political Rights (ICCPR). ${ }^{31}$

Hence it is also unclear to which universal crimes the usual prohibition of ex post facto criminal liability and punishment may not apply, or rather is not legally relevant because the offences are already before the act constituted as punishable crimes directly under international law. This principle is reflected in Article 15(2), which states that nothing "shall prejudice the trial and punishment of any person for any act or omission which, at the time when it was committed, was criminal according to the general principles of law recognised by the community of nations". Notably, the UN Human Rights Committee has still not issued any general comment on the formulation of the legality principle and the specific criminal offences "under (...) international law" as stated in Article 15 of the ICCPR, although the Committee by 1 October 2013 had issued 35 general comments, covering almost all the civil and political rights enumerated in the ICCPR. A leading commentary on the ICCPR has only brief comments on the issue of the relevant international crimes referred to in Article 15. ${ }^{32}$

A circular relationship may have occurred. That is, because international courts have lacked subject matter jurisdiction over certain possible universal crimes under international law, the scope of international criminal law with respect to these crimes has not been clarified. For example, the legality principle at the ICC according to the Rome Statute Article 22(1) applies directly only to the core crimes within the jurisdiction of the court. ${ }^{33}$ Since international tribunals have not got much chance to clarify the status and applicability of other possible universal crime types, states may not want to establish new international courts with adequate, but legally speaking possibly uncertain, subject matter jurisdiction. The might for instance have been the situation both with regard to the non-establishment of extraterritorial international anti-piracy courts and with regard to the limited international jurisdiction for terrorist crimes. ${ }^{34}$

This unclear legal situation is unfortunate, particularly because international criminal courts are needed to avoid serious fragmentation of ICL. Within the circle of the core universal crimes, such fragmentation has largely been avoided, despite the existence of

31 See ICCPR Article 15(1), first sentence: "No one shall be held guilty of any criminal offence on account of any act or omission which did not constitute a criminal offence, under national or international law, at the time when it was committed."

32 See Manfred Nowak, U.N. Covenant on Civil and Political Rights: CCPR Commentary, 2nd ed., (N.P. Engel, Kehl, Germany, 2005) p. 368. Nowak refers to customary peace and humanity, and similar provisions of international law, such as slavery and the Genocide Convention, the Apartheid Convention, the Third Geneva Convention, and the Rome Statute (p. 360).

33 See Rome Statute of the International Criminal Court, 17 July 1998, Article 22(1): "A person shall not be criminally responsible under this Statute unless the conduct in question constitutes, at the time it takes place, a crime within the jurisdiction of the court". Article 5 lists the four crime categories within the jurisdiction of the Court: genocide, crimes against humanity, war crimes, and aggression (not yet operational). On this latter point, see further Einarsen (2012) pp. 309-313. 
several international criminal tribunals operating under similar but differently framed statutes. Fragmentation has been counteracted by employing almost identical crime definitions in the courts' statutes; by having prosecutions before international courts focus mainly on genocide, crimes against humanity, and war crimes; and by targeting the most responsible perpetrators. Prosecutors, defence lawyers, and judges at the international tribunals have thus also been able to learn from the experiences of their colleagues at other tribunals and to take account of the jurisprudence developed. Formal mechanisms such as appeals chambers have also contributed towards unity. Overall, most parts of ICL under international court jurisdiction have thus far developed harmoniously. According to one observer, ICL has - presumably insofar as the core crimes are concerned - now met the principal requirement of a legal system, that of being internally consistent and predictable. ${ }^{35}$ That is particularly important since domestic legislators, prosecutors, and courts are also now more active in this arena, implying "a risk of unbridled and uncontrolled diversity". ${ }^{36}$ This experience thus shows the importance of international jurisprudence of high quality, which can be achieved in relation to specific crimes when adequate international courts are entrusted with relevant and sufficiently clear subject matter jurisdiction.

As has been made clear, the situation is less reassuring for other categories of universal crimes under international law. Paradoxically, the justified focus on the core universal crimes may have contributed to a particular kind of ICL fragmentation, which may persist if the focus is not broadened. At present, crimes satisfying the same universal crime criteria under international law are treated very differently in practice. This potentially creates a situation of inconsistency and unpredictability at the state level, for example with respect to whole categories of universal crimes, namely terrorism, crimes against the United Nations and internationally protected persons, crimes of group destruction not encompassed by the Genocide Convention, grave piracy crimes, grave trafficking crimes, and excessive use and abuse of authorised power in relation to especially serious underlying crimes. ${ }^{37}$ It would be unfortunate if these other important universal crimes were not eventually also defined in international instruments and prosecuted before competent international courts. Inherently grave crimes require retributive justice through a fair and public prosecution for a number of different and interconnected reasons. These reasons include deterrent effects as well as the need to uphold and clarify the norms un-

35 See Joseph Rikhof, "Fewer Places to Hide? The Impact of Domestic War Crimes Prosecutions on International Impunity", in Complementarity and the Exercise of Universal Jurisdiction for Core International Crimes (ed. Morten Bergsmo), FICHL Publication Series No. 7, Torkel Opsahl Academic Epublisher, Oslo, 2010, p. 78.

$36 \quad$ Ibid., p. 79.

37 See Einarsen (2012) pp. 325-328 (“Appendix I”, crime categories E through J). Whereas 85 universal crime types are classified as belonging to the core crimes in the Appendix, 65 other universal crime types are also listed (of which 14 are considered universal crimes lex ferenda). 
derpinning the proscription of the crimes. Retributive justice with formal procedures is a precondition for establishing, re-establishing, or preserving the rule of law because it emphasises compliance with substantive legal and moral norms and addresses breaches of those norms.

With respect to complex universal crimes, the experiences of recent decades with core crimes show that there are many advantages in having international courts lead the way with their procedures and eventually provide clear guidance to national prosecutors and courts on the same issues. When international guidance is more limited, fragmentation of universal norms, legal uncertainty, and even direct abuse of substantive criminal law concepts are likely to be more common at the national level. For example, the concept of terrorism under international law has probably been widely abused in some countries for the purpose of suppressing particular groups or persecuting political opponents rather than fairly prosecuting and preventing serious crimes. Such practices do a disservice both to the rule of law and to international relations more generally.

The lesson from successful international court actions on the core crimes is that it possible to remedy fragmentation and the risk of abuse of international law through concerted actions. The threat of ICL fragmentation does not come from the establishment and works of competent international courts, notwithstanding their particular legal basis and jurisdiction. What is required is that the crimes be sufficiently defined in the first place, in the court statutes, in accordance with already existing international law that is accessible and foreseeable to potential perpetrators in accordance with the international legality principle.

This brings us to the last point: the need to develop a 'United Nations Declaration on Universal Crimes' that includes all universal crimes lex lata and places them on an equal footing. Such a declaration would put potential perpetrators around the globe on notice that the world community has identified a concrete and exhaustive list of universal crimes. Perpetrators of these universal crimes would be subject to prosecution and could not invoke domestic laws in their defence.

The substantive identification processes should be carried out in a principled and just manner, proceeding further on the basis of common criteria, for example, the five criteria proposed earlier for the identification of universal crimes lex lata. When conducting new policy discussions anchored in the same agreed principles, it would be unproblematic for the UN to update the declaration regularly and thus elevate former universal crimes lex ferenda to the list. Taking such updates into account, it would be easy to determine whether a specific offence, when committed, "was criminal according to the general principles of law recognised by the community of nations". ${ }^{38}$ For the crimes included in the initial declaration, it should be stated clearly in each case from which point in time the different crimes are supposed to have been sufficiently foreseeable, in accordance with 
the international legality principle. The crime would presumably be either always a universal crime within the UN paradigm of international law, or a universal crime at least from a certain point in time.

Would a broadly supported UN declaration meet the requirements of the international legality principle? My contention is that it would, provided that the crimes included are identified using our five criteria and that the time frame for application is determined for each crime type. For this we have some precedents in international law, for example, with respect to the crime of genocide that was first declared a universal crime by the General Assembly in 1946, ${ }^{39}$ two years before the Genocide Convention was enacted. The Genocide Convention was thus premised on the normative fact that genocide was already a crime under international law, as noted in the preamble and in Article $1 .{ }^{40}$ International courts have noted this point also. In its advisory opinion on reservations to the Genocide Convention, the International Court of Justice stated:

\begin{abstract}
The first consequence arising from this conception is that the principles underlying the Convention are principles which are recognised by civilised nations as binding on States, even without any conventional obligation. A second consequence is the universal character both of the condemnation of genocide and of the co-operation required "in order to liberate mankind from such an odious scourge" (Preamble to the Convention). The Genocide Convention was therefore intended by the General Assembly and by the contracting parties to be definitely universal in scope. ${ }^{41}$
\end{abstract}

On the basis of this precedent, a comprehensive declaration on universal crimes could provide sufficient warning on inherently grave criminal conduct for individuals, powerful non-state actors and states. ${ }^{42}$ A natural first step in the process toward such a 'UN Declaration on Universal Crimes' would be for the General Assembly to entrust the International Law Commission with the mandate to prepare the first draft. Internal UN procedures ought to be complemented by broad and substantial public debate, which would be vital for the future legitimacy of such an important undertaking.

$39 \quad$ See UN General Assembly Resolution 96(I), “The Crime of Genocide”, 11 December 1946.

40 Convention on the Prevention and Punishment of the Crime of Genocide, 9 December 1948, see preamble: "Having Considered ... that genocide is a crime under international law"; Article I: "The Contracting Parties confirm that genocide ... is a crime under international law"). (Italics supplied by this author.)

${ }_{41}$ International Court of Justice (ICJ), Reservations to the Convention on the Prevention and Punishment of the Crime of Genocide, Advisory Opinion, 28 May 1951, I.C.J. Reports 1951, p. 15, at p. 23.

42 The importance of such appropriate warning has recently also been recognised by the Extraordinary Chambers in the Courts of Cambodia (ECCC). See ECCC, Pre-Trial Chamber, Decision on Ieng Sary's Appeal against the Closing Order, 11 April 2011, paras. 246-249 (regarding genocide) and paras. 250-254 (regarding crimes against humanity). 
Bergen Journal of Criminal Law and Criminal Justice $\bullet$ 1/2013

\section{Conclusions}

This article has pursued the notion of 'universal crimes' as a fruitful supplement and alternative to the traditional term 'international crimes'. It proposes preparation of a 'UN Declaration on Universal Crimes', with the objective to clarify authoritatively and in a principled manner the status and lawful application of all relevant crimes under general international law.

Academics and others can in the meantime do more to elucidate and possibly reduce some of the uncertainty surrounding several distinct crime candidates. Further analysis of the concept of universal crimes and its scope for application may contribute towards this end, and thus eventually also to a less fragmented international criminal law. 